THE AC A D E M O F F I S T I U F F S 


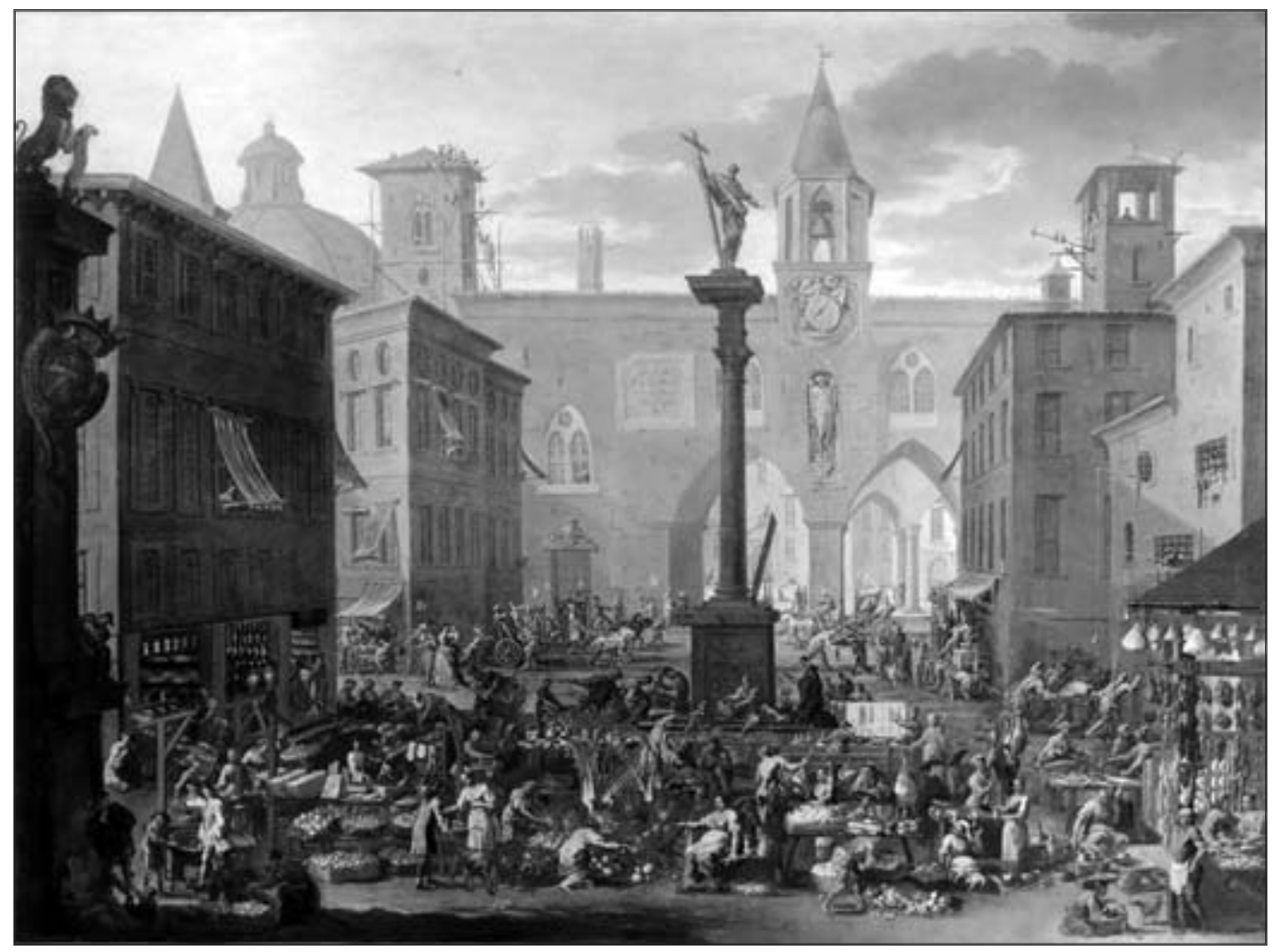




\section{The Academy of Fisticuffs}

P O L I T I C A L E C O N O M Y A N D

C O M M E R C A L S O C I E T Y I N

E N L I G H T E N M E N T I T A L Y

Sophus A. Reinert

Harvard University Press

Cambridge, Massachusetts

Sondon, England

2018 
Copyright (C) 2018 by the President and Fellows of Harvard College

All rights reserved

Printed in the United States of America

First printing

Frontispiece. Alessandro Magnasco, Il Mercato del Verziere, I733.

Raccolte d'Arte Antica, Pinacoteca del Castello Sforzesco, Milano Raccolte.

Copyright (C) Comune di Milano-All rights reserved.

Jacket design: Tim Jones

Jacket art: Bare-knuckle boxing, c18th century, Courtesy of HIP / Art Resource.

9780674916197 (EPUB)
9780674916203 (MOBI)
9780674916I80 (PDF)

The Library of Congress has cataloged the printed edition as follows:

Names: Reinert, Sophus A., author.

Title: The Academy of Fisticuffs : political economy and commercial society in Enlightenment Italy / Sophus A. Reinert.

Description: Cambridge, Massachusetts : Harvard University Press, 20I8. | Includes bibliographical references and index.

Identifiers: LCCN 20I8006858 | ISBN 978067497664I (alk. paper)

Subjects: LCSH: Accademia dei Pugni. | Verri, Pietro, I728-I797. | Beccaria,

Cesare, marchese di, I738-I794. | Enlightenment—Italy—Lombardy. |

Socialism—Italy—Lombardy—History—I8th century. | Lombardy

(Italy)-Economic conditions-I8th century.

Classification: LCC B802 .R434 2018 | DDC 945/.07-dc23

LC record available at https://1ccn.loc.gov/2018006858 
Til Erik August

Er der nogen nærmere, end Fader og Søn?

-Henrik Ibsen, De unges Forbund (I869) 

Lions, wolves, and vultures don't live together in herds, droves or flocks. Of all animals of prey, man is the only sociable one.

-John Gay, The Beggar's Opera, I728 
